Yu. V. Honcharov ${ }^{1}$, orcid.org/0000-0002-3800-8038,

I. Yu. Shtuler ${ }^{2}$, orcid.org/0000-0002-0852-8526, V.V.Serzhanov ${ }^{3}$, orcid.org/0000-0002-0577-4422, T. O. Makukh ${ }^{4}$ orcid.org/0000-0002-7120-7231
1 - Academician Stepan Demyanchuk International University of Economics and Humanities, Rivne, Ukraine, e-mail: goncharov_yv@ukr.net

2 - National Academy of Management, Kyiv, Ukraine

3 - Uzhhorod National University, Uzhhorod, Ukraine

4 - Rivne Institute of the University "Ukraine", Rivne, Ukraine

\title{
PARADIGM OF STATE REGULATION AND STRUCTURAL TRANSFORMATION OF THE NATIONAL ECONOMY FROM THE STANDPOINT OF HOMEOSTASIS
}

Purpose. The work presents the substantiation of the paradigm of state regulation and structural transformation of the national economy. The problem that is raised is the question of the existence of the national economy to development from the standpoint of homeostasis through the analysis of the current situation for compliance with the prevailing conditions and the ability to adapt to change.

Methodology. In the course of work, research was carried out based on the key provisions of modern economic theory and the latest concepts of economic development. Methods of theoretical modeling and structural-logical analysis, systematization, grouping, logical generalization are used. To achieve the goal, general and special methods of research on processes and phenomena were used, namely: methods of theoretical analysis and synthesis to explain the processes of interconnection, highlight key elements and characterize other important categories for research. The application of the system-structural approach made it possible to reveal the paradigm of state regulation and structural transformation of the national economy from the standpoint of homeostasis.

Findings. The gradual development of any economic system is cyclical; the negative impact of market fluctuations is marked. One of the conditions, inherent in development, is the transformation of the economic system caused by the crisis. At the micro level for the economic system, the content, state and depth of the crisis is manifested in the exacerbation of contradictions, which does not allow the full use of national resources. At the macro level, this is manifested in an increase in the number of the unemployed, lower capacity utilization, and so on. Such an economic situation requires a new paradigm of state regulation and structural transformation of the national economy from the standpoint of homeostasis. Development trends of other countries and the potential of Ukraine determine the multiplicity of ideas by combining elements of world experience of economic development models. It is established that the "ideal" model of national economy development within the new paradigm of state regulation and structural transformation of the national economy from the standpoint of homeostasis should be taken into account when creating a comprehensive system of integrity and security of the national economy depending on the external environment.

Originality. The originality of the research consists in finding an effective combination of internal and external mechanisms, imperatives, methods and tools that must be considered when creating a comprehensive system of economic development. One of the areas of improvement is to build a model of such development from the standpoint of homeostasis within the paradigm of state regulation and structural transformation of the national economy. The concept of homeostasis is currently fundamental in the development of society. According to the results of scientific research, the forms of influence on the development of the national economy from the standpoint of homeostasis are determined, and a generalized structural and logical scheme of organization and regulation of the national economy from the same perspective is proposed.

Practical value. The results of the study can be used by government officials, scientists and practitioners to develop scenarios for the economic development of the national economy.

Keywords: economic system, equilibrium, homeostasis, stability, socio-economic development

Introduction. The end of the twentieth century for the world economic system was marked by transformational transformations in all spheres and at all levels. Their understanding focused the attention of scientists on the establishment of qualitative changes that are formed at the initial stages of economic growth and the need for structural changes that encourage economic development and growth.

Globalization processes have led to integration in all spheres of society: economic, social, political, cultural, demographic, and others. Rapid changes in key indicators and the extensive development of the global environment require increasing attention in the search for new ideas of economic development both at the national level and in the global dimension. It is necessary to radically change the economic policy and economic model of the country, concentrating resources and efforts in the right direction and, most importantly, to do so from the standpoint of homeostasis.

Literature review. Theoretical, methodological and practical problems of development and growth of national economies

(c) Honcharov Yu. V., Shtuler I. Yu., Serzhanov V.V., Makukh T. O., 2020 have never lost their relevance. Among those scientists who have dealt and are dealing with theoretical and applied issues of national economy and whose work has influenced the formation of the author's opinion in a particular area of research, it is worth noting the works by: O. Amosha, V. Heiets, V. Halasiuk, A. Galchinsky, M. Yermoshenko, S. Yerokhin, T. Kovalchuk, V. Cherniak, V. Shevchuk, and others.

Unsolved aspects of the problem. The research shows that an evolutionary scenario of economic growth of $3 \%$ per year will never bring Ukrainians European prosperity. In order not to preserve the economic backwardness and achieve economic European integration, Ukraine needs to take care of the development of the national economy from the standpoint of homeostasis. Unfortunately, not enough attention is paid to these issues at present. It is also necessary to target economic growth at least $7-8 \%$ per year and ensure it for a long time. This can be done by implementing appropriate strategies and development tools, taking into account the position of homeostasis.

The model of national economy development from the standpoint of homeostasis should be taken into account when creating a comprehensive system to ensure the integrity and 
security of the Ukrainian economy as required by the paradigm of state regulation and structural transformation of the national economy from the standpoint of homeostasis. The article considers the diversity of interpretations of the term "homeostasis" by scientists, establishes that the concept of homeostasis is a global paradigm of modern society, identifies forms and types of state regulation and self-regulation of the national economy and on this basis proposes a generalized structural and logical scheme positions of homeostasis in the form of an appropriate strategy, set of measures and tools for development.

Purpose. The purpose of the article is to study the paradigm of state regulation and structural transformation of the national economy from the standpoint of homeostasis. Maintaining the existing model and moving by inertia is the way to the loss of economic capacity. Under such conditions, the importance of defining clear guidelines for Ukraine cannot be overestimated: where to move in order to minimize resistance and gain a vision of a 15-20-year perspective. Currently, due to the high degree of uncertainty inherent in any transformation period, insufficient development or lack of decision-making models and the lack of appropriate information base, this period can be defined as transitional. Defining clear priorities involves the transformation of all system-forming components of the national economy with a certain synchronization of all processes. This is what determines the content and nature of the necessary reforms.

Methods. To achieve the aim of this article, general scientific and special methods of research on processes and phenomena are used, namely: methods of theoretical analysis and synthesis, system-structural approach, method of theoretical modeling and structural-logical analysis, systematization, grouping, logical generalization. In general, in the process of working on the article, research was carried out based on the key provisions of the modern economic theory and the latest concepts of economic development.

Results. Economic development issues are of concern to most countries in the world and are among the key and most difficult ones. After all, it is impossible to build a technologically advanced and socially oriented European country using destructive neoliberal advice or examples of economic outsiders. And today, in the period of formation of post-industrial society, there is an urgent need for the transition of state orientation from the quantitative parameters of economic development to its qualitative characteristics. Global economic imbalances and crises in national economies encourage the search for new ideas of economic development that shape the modern paradigm of state regulation and structural transformations from the standpoint of homeostasis. Limited access to external resources of financial and technological markets requires solutions that allow eliminating a set of problems caused by the movement of a particular route. This problem is especially acute in Ukraine, which is in dire need of a radical acceleration of economic growth. Confirming this is the lag of the national in all criteria, especially in scientific, technical and technological characteristics, which are key growth factors in modern conditions. The consumer approach to national wealth, based on the sequence of actions of "extraction of natural resources - sale of these resources - distribution of rental income among beneficiaries" has lost relevance. Accordingly, former development ideas are currently ineffective and have lost their urgency. This conclusion was reached by most of the world's scientists, who during scientific discussions note that "further sliding of the country into the zone of" deep periphery "of economic development does not suit anyone" [1]. This requires the introduction of a new paradigm of state regulation and structural transformation of the national economy, making a radical turn in economic policy. Most support the idea of the concept of "homeostasis", which includes government regulation without excluding the mechanisms of market self- regulation [2]. As a result, the problem of finding mechanisms, models and strategies that can, not only in the short but also in the long run, increase productivity and competitiveness of economic systems, reduce sensitivity to external fluctuations and negative globalization and more. It is not enough to predict economic processes and dynamics - it is necessary to design and "build" them in accordance with the needs of society.

Globalization plays a separate structural role in building interdependencies and interactions between countries in the world economy. However, despite all the positive aspects of globalization, there is a negative impact on the economies of related countries in this process. This implies the existence of contradictions between large-scale (global) and social interests of the country, the dominance of highly developed countries over less developed ones, which extend their influence not only to the country's economy, but also to all other areas.

At the beginning of the third millennium, global transformations, as a phenomenon of the modern world economy, are increasingly drawing the economies of countries in which market processes are in their infancy into their "orbit". As a result, in some countries there is a tendency to gradually transfer some management functions to supranational organizations for external control (the UN, European Parliament, IMF, WTO, and others).

If at the beginning of the $21^{\text {st }}$ century there were only 37 international state organizations and 17 international nongovernmental organizations, then as of 2000 there were already 6743 international state organizations and 47098 international non-governmental organizations. In addition, the number of international regulatory agreements that change the internal environment in states has increased significantly. Note that from 1976 to 2000, more than 1700 international agreements were concluded, of which more than 100 - related to the establishment of international organizations [3].

One of the important factors in the development and further spread of globalization is world trade.

The accelerated development of world trade largely depends on the world system of trade regulation, which was formed in the second half of the XX century. It is based on the General Agreement on Tariffs and Trade (GATT), which entered into force in 1948 and was updated from time to time in accordance with changing market conditions. On the basis of GATT in 1995 the modern well-known international organization World Trade Organization (WTO) was created. The main purpose of its creation and operation is the implementation of international trade, removal of obstacles to the flow of goods and services that would contribute to discrimination, free access to national markets and sources of raw materials.

Ukraine's accession to the WTO at one time was of strategic importance for the national economy. First: it is the further integration of the country into European and world processes. Secondly, it is a systemic reform of the national economy in accordance with the principle of openness. But there are downsides to this process. The main thing is that domestic enterprises need to make a lot of efforts to be competitive. The fact is that firms compete in the international market, not countries. It is they who create and maintain competitive advantages supported by the state. The state itself, in accordance with its functions, creates conditions, coordinates and stimulates the activities of enterprises in the international market.

The tools of state regulation of the development of the national economy in the context of globalization were formed at the beginning of the transition of market relations, but the country's leadership has not always consistently led the transformation process. Sources of negative effects on economic security could be:

1) conscious and unconscious actions of officials and business entities;

2) coincidence of objective circumstances (global financial crisis, political crisis of the authorities). 
Modern production and financial structures have gone beyond national borders and become truly global. However, the new global economy has not resolved the contradiction between the wealth of industrialized countries and the poverty of developing countries.

Tracking the dynamics of the system of international organizations can be seen the growing influence of highly developed countries on the functioning of world organizations: this is especially noticeable in the activities of the IMF, World Bank, World Trade Organization, which often represent the interests of the strongest states.

Nobel laureate in economics Jeffrey Sachs recorded 173 cases when in countries where the IMF was a kind of "commander" for the observance of monetary beacons, the macroeconomic and social situation deteriorated significantly and thus provoked fierce confrontation between government and society.

The main shortcomings, and often contradictions in the regulation of the global economy at the present stage are:

- the predominance of issues of economic growth and financial stabilization over the social problems of society;

- dependence of the decision-making process on "rich" countries at the global level, "poor" countries, as a rule, are not represented at all;

- prevalence of decisions of a recommendatory nature taken by international organizations, rather than mandatory ones;

- lack of mechanisms that must ensure compliance with moral standards and human rights by corporations and firms;

- weak control functions in the field of international activities, which, as a consequence, leads to increased influence of transnational corporations;

- insufficient efficiency of the staff of international institutional structures [4].

All these above-mentioned shortcomings testify to the inevitability of reforming the international regulatory system.

However, there is no unanimous opinion on the further development of the world's national economies or individual integration entities. At the beginning of the last century, J. Schumpeter [5], and later a number of other economists, laid in their works a theoretical basis for studying the materiality, patterns and specifics of the evolution of economic systems. Their work allowed outlining the laws of technological evolution and the role of innovation at various stages of the long cycle of science and technology, substantiating the idea of interaction and interdependence of technological changes and institutional changes, the interaction of technological and socio- economic evolution, as well as analyzing approaches to innovation classification.

Studies on economic systems of the transitive type, as a rule, are based on the distinction between two historically composed and well-studied models of development - importsubstituting and export-industrial. At the same time, the identification of the import-substituting model with the closed type of economy and the export-industrial model with the open one leads to a sharp polarization of views on the problem of choosing the path of development and the nature of the ongoing reforms. In Ukraine, discussions on these issues are influenced by the intertwining of economic and geopolitical approaches. There are two geopolitical factors that influence the formation of the typology of economic thinking.

The first factor. Ukraine's location on the border of West and East and the problem of "Eurasianism", which has not been solved for a long time. Accordingly, in economic research, the pendulum of beliefs ranges from concepts of development on the type of Western countries to theories of strengthening the alternative principles of the "Japanese miracle", and so on [6].

The second factor. Ukraine's place in the group of countries "catching up with industrialization" and a serious lag behind technological leaders. In this aspect, the most disagree- ment is over the choice of development model. Some interpret the technological backwardness as the reason for the impossibility of further movement of the Ukrainian economy in line with the import-substituting model. Other researchers emphasize the growing dependence of Ukraine on the world economy in the case of full openness of its economy [7].

Indeed, the historically industrial type of development could only be realized on the basis of an import-substituting model that originated in the West. The breakthrough of a country in the group of technological leaders was carried out as a result of the formation of its economy reproductive cycle.

The most important prerequisite for the creation of industrial bases of the economy is the availability of natural resources in the national economy, which limits the development of countries that do not have sources of raw materials. The export-industrial model, called "dependent industrialization", was formed as a means of adapting to the integration trends of the industrial period, which led to a later connection to the technological development of Japan and the countries of the Asia-Pacific region. The import-substituting model of the industrial period created a classic example of the formation of innovation flows in the economic system. We are talking about the emergence of basic innovations in heavy industry, the direction of the distribution process, the diffusion of innovations from the sector of production of means of production to the sector of production of durable goods. Thus, J. Schumpeter connects the mass emergence of "new combinations" and the growth of capital investment, first of all, with the greatest recovery in the industries that produce means of production, with the growth of steel consumption. The distinction of the new technical and economic paradigm from the previous ones, within the framework of the industrial period of development, is the loss of the sectoral orientation of the spreading sectors [8].

At this stage we are talking about the development of the economy as a whole, about changes in its evolution, the nature of existing patterns. The dominant technological component of modern economic policy in developed and developing countries has significantly modified the content of import-substituting and export-industrial models as such. The policy of import substitution has lost its significance as a means of creating a relatively separate national economic system, but remained as a measure to ensure technological renewal of the structure of the economy [2].

Accumulation of innovations at the stage of import substitution allows intensifying the foreign trade balance due to higher competitiveness of exported goods. In turn, the growth of export operations determines the inflow of capital into the country; growing demand will give impetus to increase the effect of capital investment. It is noteworthy that $90 \%$ of research is carried out by US multinational corporations in their country, about $8 \%$ in their branches in developed countries and only $1 \%$ in underdeveloped countries. The most important criteria in the use of import substitution policy were the concentration in the national economy of technological flows coming from outside, the creation of an information field. At the same time, there is a tendency to place industrial production outside the national economy. Thus, in the US economy, an increasingly important role is played by the creation of an information network capable of tracking the production of industrial products in the world economy. The understanding of the import-substituting model as a stage necessary to maintain the dynamics of the national economy in line with world trends, strengthened in connection with the development of concept of "flocks of flying geese" by Japanese economist K. Akamatsu more than half a century ago. For the economies of the Atlantic and Pacific basins, import substitution is seen only as the degree to which innovation is adapted and standardized. At the stage of export in many 
cases there are qualitatively new characteristics of the product that will allow it to be attributed to a new basic innovation [9].

The essence of the export-industrial model is subject to similar changes. The most important strategic object of integration is new technology, while the production of industrial products is transferred to less developed, but richer in natural resources. This process is clearly traced through the strengthening of the industrial expansion of the AtlanticPacific region to the European continent. With the growing role of developing countries in the international division of labor, the importance of the alternative classical scheme of the phenomenon of the spread of innovation flow increases from the sector of production of durable goods to the sector of production of means of production.

Major introduction of innovations in the sector of production of durable goods increases the technological mobility of the economy of countries where there will be no problem of structural and innovative restructuring of the sector of production of means of production. In turn, the stage of import substitution is formed in this group of countries on a new technological basis compared to countries that have previously embarked on the path of industrialization [2]. Examining these trends, it is easy to see that once fundamentally different models of development lose their originally clear outline, which gives grounds for their differentiation.

Disagreements begin as soon as the question arises as to the direction in which new solutions should be sought and how to ensure the convergence of national economies to the centers of the modern evolutionary process. To ensure the solution of this issue, it is necessary to identify the conditions for finding new development ideas. After all, the correct solution to the problem of ensuring effective and sustainable development of the national economy in modern conditions involves the implementation of a set of interconnected transformations aimed at expanding the resource base, activating the human factor, updating the institutional framework. In assessing their prospects, one should also bear in mind that many of the socio-economic transformations initiated in recent years have not yielded the expected results, and have either stopped halfway or remained on paper.

At the same time, in the transformation field of various world economies a new round of reprivatization is taking place, as a result of which the level of competitiveness and attractiveness of business for potential investors decreases, bureaucratization and corruption intensify, which leads to a violation of the mechanisms of public and corporate governance, alienation from the economies of developed countries increases [10].

This is confirmed by the dynamics of the Global Competitiveness Index of Ukraine for 2000-2018, which in case of lowering the ranking indicates the need to find new ideas for the development of national economies, as well as the readiness of countries for the next stage of the industrial revolution. Thus, according to this rating (Fig. 1), in 2018 Ukraine lost 27 positions against the level of 2000 , occupying position 83 among 140 countries [11].

Against the background of large-scale outflow of capital generated by the economy of Ukraine, there was an acute shortage of financial resources, which limited the opportunities for its further development. The processes that have taken place since the beginning of the $21^{\text {st }}$ century have led to the alienation of the country from the core of the world evolutionary process and pushing it to the far periphery. All this flared up in the desire to find a special national path of development. In many cases, such searches are reduced to dreams of returning to a centralized economy, which is evidence of a shortage of new ideas of development, which are trying to fill with memories or ideas [12].

Historical traditions in the development of national economies and the existing economic potential determine the scatter-

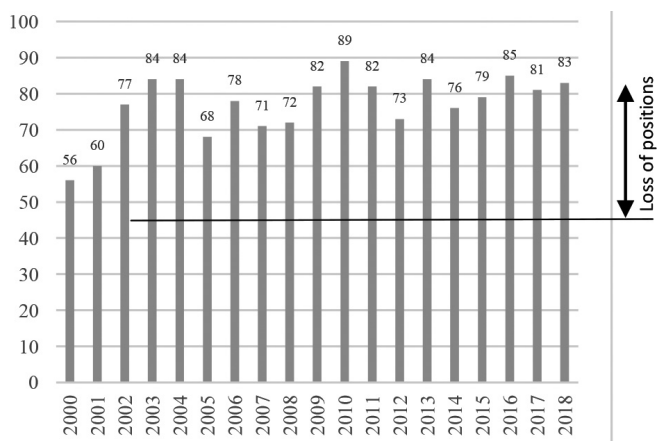

\section{Fig. 1. Ukraine's place in the Global Competitiveness Index in 2000-2018 [11]}

ing of ideas through the synthesis of elements of different models of economic development. Despite the growing trends of elements of import-substituting and export-industrial models in economic policy, there are significant differences in the development strategies of the national economy between countries [12] (Shevchuk V., Shevchuk D.).

There are four stages of competitive economic development: stage of development based on factors of production: stage of investment development; stage of innovative development; stage of development based on well-being [12].

Historical traditions in the development of the national economy and the existing economic potential determine the scope of possible production guidelines through the synthesis of elements of these models. Despite the tendency to combine elements of import-substituting and export-industrial models in economic policy, the strategy to support innovation remains different between countries.

American economists who studied the "economic miracle" in South Korea were surprised by the state of local businesses. Many successful Korean companies were, by US standards, bankrupt companies with an annual economic growth rate of $10-15 \%$. And it is not just about differences in the means of national accounting. In an environment where the country's competitiveness in world markets is less and less based on traditional factors and increasingly on those activities that are based on knowledge, the practice of governments supporting not only basic research but also applied development and implementation of innovations becomes widespread. The latter measure is sharply criticized by adherents of orthodox means of regulation. The model of economic growth in the framework of orthodox equilibrium theory is based on an innovative model, according to which the formation of technologically advanced industries is based on credit issuance at future value. That is creating a new purchasing power in addition to the appeal that existed before. This is precisely the source from which, in typical cases, the implementation of new combinations is financed. Targeted lending at future value reduces the duration of the depressive period in the economic cycle; artificial narrowing of the money supply in the national economy is replaced by government regulation and support for the flow of monetary resources in the most promising, in terms of longterm development, sectors of the economy. The probability of inflation spikes is inversely related to the correct choice of production benchmarks. The concepts of credit issuance at future value are in line with the results of research conducted by G. Mensch and devoted to the concentration of basic innovations in the phase of depression. He stressed that the introduction of basic innovations at this stage of development is the only opportunity for profitable investment, and in the end "innovations overcome the depression" (G. Mensch). 
There are many works on this issue, including D. Northcott's "Investment Decision Making", which addressed the problems of development and implementation of innovations in the economy [13]. The focus of the orthodox monetary school on the analysis of the balance of economic systems narrows the possibilities of predicting the future, as well as the use of targeted measures, which is especially important for developing countries and transitional economies. The concept of credit issuance at future value, on the contrary, is based on the development of a technological strategy for economic development. Lending at future value is typical for countries undergoing technological renewal. It is associated with the formation of a "long wave" in the economy, which determines the nature of its development in the next 50-60 years. Hence the conditions of lending aimed at clustering in the economy of innovations based on the synthesis of elements of import-substituting and export-industrial models, taking into account the national specifics of the economy and world trends.

Clusters of innovations of the latest technical and economic paradigm are formed mainly in the field of informatics and communications. It is in this area that the state concentrates its efforts in developed countries. Transformation processes in transitional economies disrupt not only innovation but also the institutional sphere. The state should more actively stimulate the process of forming clusters of innovations in the economic structure. As the experience of dynamically developing countries shows, the "retreat" of the state can be justified only when achieving stable growth, which means the presence of stable innovation flows into the manufacturing sector, their adequacy to state national security policy. In the countries of the Asian basin, in accordance with the chosen innovation benchmark, state support for risk areas is provided.

Fifteen years ago, the state regulation of these countries marked the transition from conventional investment to "dynamic science and technology policy". It is a set of specific investments that form a set that combines a single conglomerate of new technology and products with knowledge, management, personnel policy and technology markets, including communication and information infrastructure. The changes in the economy related to the "consumption accumulation" ratio go beyond the current stabilization policy. Meanwhile, it is the institutional innovations carried out in its direction that determine the future structure of the economy [8].

Implementation in economic policy of the thesis of the orthodox monetary school on the narrowing of short-term effective demand and exacerbation of sales as a result of increasing investment in production in its literal sense leads to a shift in business interests to speculative nonproductive profits. In Ukraine, the problem of profitability of enterprises, especially with a long production cycle, contradicts the existing system of structural and credit policy. Unprofitable in the innovation complex are precisely those measures that determine the conditions for long-term development of the technological basis of production and are included in the concept of "implementation of new combinations". An important role in creating a favorable investment climate for production is played not only by interest rates on loans, but also by their conditions. Unfortunately, not in Ukraine, but, for example, in Korea, there is a form of deferred payment, which allows companies to make payments not from current but from future profits by accumulating it and increasing production volumes. Thanks to this measure, it is possible to develop markets faster and more efficiently due to the relatively low price of a new product, because the cost of credit is not included in the costs. Technological diversity of the Ukrainian economy is the reverse side of its technological backwardness.
The protracted nature of the Ukrainian technological downturn today leaves no room for leveling the elements of the productive structure on the basis of a higher technological structure, as proposed by supporters of the importsubstituting model of industrialization. Carrying out such a policy in conditions of stagnation is almost impossible. At the conceptual level, Ukraine's economic strategy must take into account evolutionary trends that play a dominant role in shaping the modern system of the world economy. The Ukrainian economy faces two interrelated tasks: the implementation of import-substituting policy, based on its new understanding as a stage necessary for the creation of a single internal market, is carried out simultaneously with the focus on export-industrial participation in the international division of labor. It is known that the equilibrium in transitional economies, which is achieved as a result of uncivilized means, can be established at a fairly low level. For example, even now Ukraine continues to rapidly approach the group of underdeveloped countries (Shevchuk V., Shevchuk D.).

The growing dependence of Ukraine on foreign trade relations and the "cut-off" of industries, especially manufacturing, were the result of the focus on the "open" economy, in which the policy of import substitution was rejected. Due to this, the opportunities to increase the competitiveness of domestic products in world markets were undermined, not to mention the decline in the share of scienceintensive production, almost the collapse of the national reproductive cycle. The formation of the stage of import substitution, which provides an industrial type of "open" economy, is based on the gradual convergence of different technological modes, the transition from rigid vertical production links to flexible horizontal as a result of penetration of elements of new technological structure, in particular, information and communication systems, into every part of the economic structure. The formation of many horizontal technological chains, including internal economic relations and at the same time going beyond the national economy will ensure the duration and create the potential for future development. Thus, the concept of "growth points" in the economy does not coincide with the sectoral or even intrasectoral approach.

This position is consistent with the analysis of the spread of innovations at the stage of import substitution, which showed the presence in both cases of an epidemic effect: the effect of direct and feedback in the diffusion of innovations (K. Akamatsu) [9], "secondary waves" (J. Schumpeter) [5].

The effect of direct communication is manifested in the fact that if one industry consumes the products of another, which uses new combinations, the first also stimulates the transition to their use. On the other hand, those industries that supply their products to companies that have embarked on the path of new combinations, receive an impetus to development by increasing demand. This pattern determines the presence of a feedback effect in the dissemination of innovations. The intertwining of direct and feedback effects provides an economic boost by both expanding the scope of new combinations and preserving old production capabilities that were previously considered inefficient. To activate the existing potential of advanced technologies in the country, it is necessary to use credit issuance. Priority support of advanced developments creates conditions for the formation of the modern structure of the Ukrainian economy and promotes the emergence of significant export opportunities that will allow it to enter foreign technological markets. Thus, J. Schumpeter notes that in times of crisis and depression, new enterprises suffer much more than the old ones (the latter have a kind of shock absorber in the form of quasi-rents, accumulated reserves and ties). "We can talk about the "selection process" carried out by the crisis only with significant restrictions, because well-off enterprises 
are not perfect at all, and only the best of them have prospects to survive the crisis" [9].

Based on the knowledge and understanding of the basic theories of economic equilibrium and the search for ideas for the development of the national economy, basic and alternative scenarios of world economic development are developed. Development in the above concepts and models is associated with cyclical or directional (linear or nonlinear) procedural changes, their single or multi- vector ("texture" - in the theory of factors), unambiguous (natural-historical) determinism or the presence of alternatives, evolutionary or abrupt (the nature of political, economic and socio-cultural transformations, the degree of their "artificiality" and "naturalness" [14]. Research in recent years has studied certain types of economic equilibrium (primarily market equilibrium) or use the concept of "economic equilibrium" as a general principle of analysis of economic processes, without detailing its content. Thus, the idea of development of the national economy is seen as a movement towards an ideal state - economic equilibrium, which is provided by the currently optimal proportions of the structure of the economy. Such a movement becomes possible due to the complex interaction of mechanisms of cyclical development, pricing, competition, accumulation and transfer of capital.

Efforts and the ability of the economic system to maintain equilibrium are understood by Reisberg as homeostasis [15]. The concept of homeostasis of the economic system is based on dynamic processes, as the sustainability of the internal environment (of each individual country) is constantly disturbed and also continuously restored.

Logical in determining the economic development of the national economy will be scientific research which will be based on the initial definition of the general, specific and philosophical content of such a concept as homeostasis.

The concept of homeostasis as a result of the action of builtin mechanisms for regulating the viability of machines and living organisms was introduced by N. Winner in cybernetics [16].

The concept of homeostasis of the economic system is based on dynamic processes, as the sustainability of the internal environment (of each individual country) is constantly disturbed and also continuously restored.

The foundations of this concept were laid by W. Kennan and R. Ashby in the first half of the twentieth century. Later, the idea of economic equilibrium was developed by other foreign scientists. In particular, G. Mensch considered "homeostasis" as "the desire of the economic system to reach a state where innovation has formed proportions that ensure effective interaction of commodity-cash flows and prices". That is, the emphasis in his research was on the desire to establish proportions. B. A. Reisenberg interpreted "homeostasis" as "the effort and ability of an economic system to maintain an equilibrium state that characterizes its stability, stability, and conservatism" [15]. That is, the concept of homeostasis of the economic system is considered by him as an effort and ability to maintain equilibrium. Yu. M. Gorsky interpreted the term "homeostasis" as "a functional state of the system, in which due to the action of special control systems provides support for the dynamic stability of vital functions and parameters of the system with various changes in internal and external environment" [17]. Interpretation of the term "homeostasis" has also been developed by other domestic scientists. In particular, M. Yermoshenko in his research [2] cited the concept of economostasis and interpreted it as "an ability of the economic system to maintain its equilibrium state and a set of properties under the influence of environmental factors, the action of which is based on information". That is, homeostasis was considered by him in terms of maintaining the equilibrium of the economic system, highlighting the role of information.

Scenarios of world economic development can be developed on the basis of knowledge and understanding of basic theories of economic equilibrium. As a rule, three scenarios are developed: pessimistic, optimistic and optimal ones. Preliminary research shows that it is quite possible for Ukraine to accelerate economic growth from $2-3$ to $5 \%$ per year. In Fig. 2, the trajectories of economic development are presented according to three alternative scenarios.

The practical significance of this scientific problem is amplified in the post-crisis conditions of functioning of global financial markets, which are characterized by a significant level of uncertainty about future trends and a high tendency to change key indicators.

Modern methodology of economic development has all the necessary tools to assess the current situation and identify major trends in the world economy. However, it should be remembered that the mathematical formalization of theories of economic equilibrium should be carried out with a detailed explanation of the reservations, limitations and assumptions that determine the conditions of formalization [18].

Successful application and use of centuries-old concepts and theories will avoid imbalance in the development of any economic system, even when in modern economic conditions, new requirements for the functioning of the economic system. The main and painful issue remains the search for an ideal state when the economic system and the external environment, being in constant and complex interaction and influencing each other, would provide the country with the appropriate level of its development.

Thus, the concept of homeostasis, with a methodological and systemic approach is a paradigm of modern society, especially in terms of efficient functioning of the economy. The concept of development of the national economy from the standpoint of homeostasis is based on the creation of an appropriate structure and infrastructure, which provides for multilevel and the existence of mechanisms of state regulation and mechanisms of market self-regulation. In a globalizing environment, the main essence of the national economy from the standpoint of homeostasis includes components that characterize the capabilities and readiness of economic systems at different levels for transformation and is to complement and adjust management approaches to balance the interests of state, business and population. Forms of influence on the national economy and its development are shown in Fig. 3, due to the provision of the general principle of spatial organization of the national economy in terms of national priorities.

Thus, the idea of developing the national economy from the standpoint of homeostasis is to find an effective combination of internal and implemented mechanisms, as well as appropriate tools and methods. From this position, the search for an "ideal" model of coexistence of market mechanisms of self-organization and state regulatory imperatives becomes especially important. Such an "ideal" model of national economy development within the new paradigm of state regulation and structural transformation of the national economy from the standpoint of homeostasis should be taken into account when creating

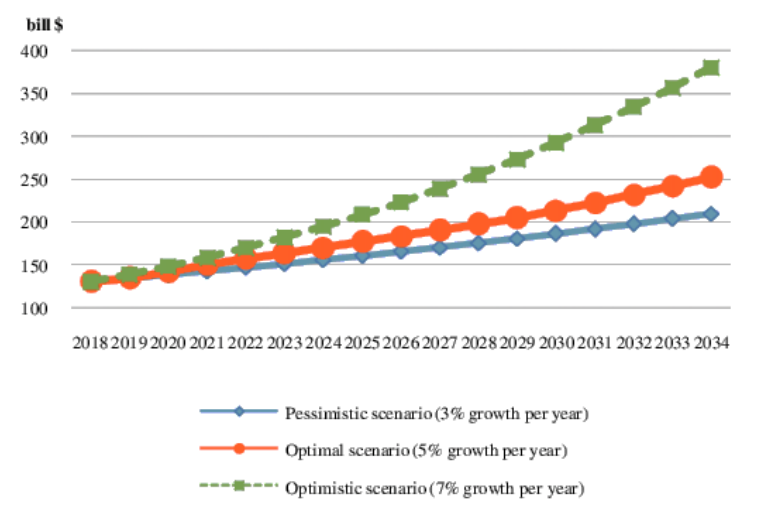

Fig. 2. Alternative scenarios of economic development of Ukraine 


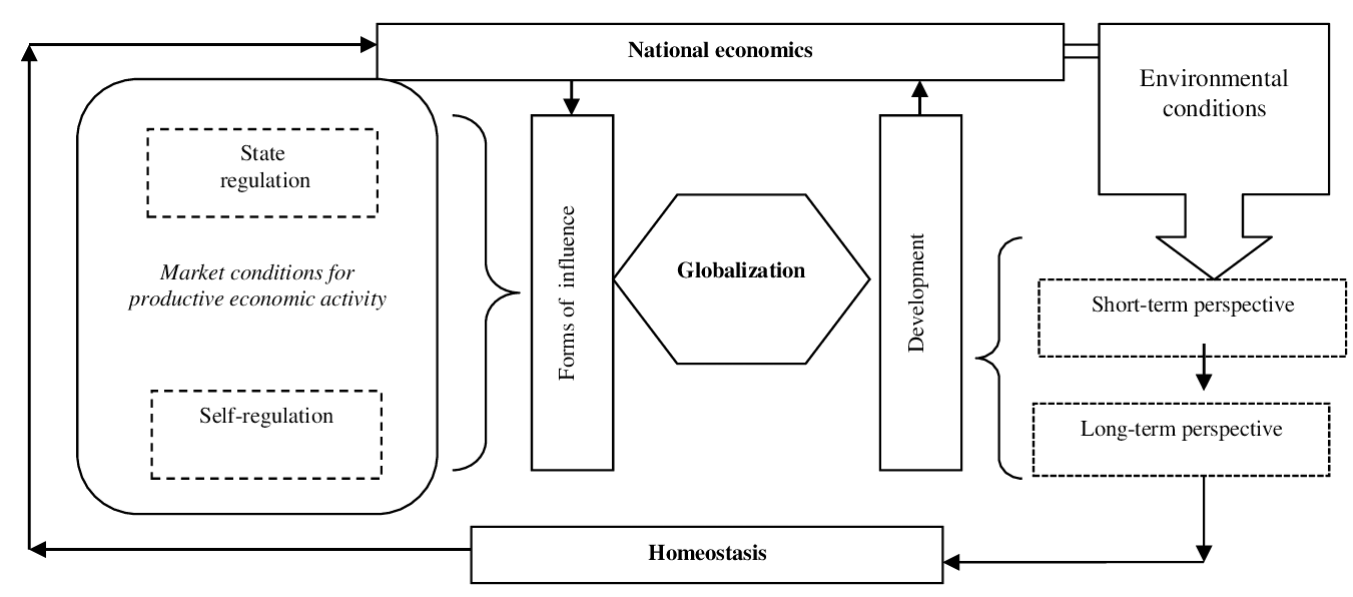

Fig. 3. Forms of influence and development of the national economy from the standpoint of homeostasis

a comprehensive system to ensure the integrity and security of the national economy depending on the external environment.

In the developed countries of the world, the existence for development is determined by the principles of concentrating on the priority areas of research, effective relations in the financing of basic research and regional development programs [3].

Based on the above, we can propose a generalized structural and logical scheme of organization and regulation of the national economy from the standpoint of homeostasis in the form of an interdependent set of measures (Fig. 4).

Conclusion. The results of the study allow us to draw the following conclusions:

- consumer approach to national wealth, global economic imbalances and crises in national economies encourage the search for new ideas of economic development;

- in the transformation field of various economies of the world there is a new round of reprivatization, which reduces the competitiveness and attractiveness of business for potential investors, intensifies bureaucratization and corruption, which leads to disruption of public and corporate governance, increasing alienation from developed economies;

- historical traditions in the development of national economies, significant differences between countries and economic potential determine the spread of ideas through the synthesis of elements of different models of economic development.

Given the above, it is important that the paradigm of state regulation and structural transformation of the national economy from the standpoint of homeostasis should correspond to the model of national economy and be taken into account when creating a comprehensive system to ensure the integrity and security of the national economy. As a result, the article considers the diversity of interpretations of the term "homeostasis" by scientists, established that the concept of homeostasis is a global paradigm of modern society, identified forms and types of state regulation and self-regulation of the national economy. Such a triad is a powerful tool in the modernization of economic policy, which significantly contributes to the complexity and efficiency of the economy as a whole. Depending on the choice of the further course of economic policy, three main scenarios of development open up for Ukraine: pessimistic, optimal and optimistic ones. The article proposes a generalized structural and logical scheme of organization and regulation of the national economy from the standpoint of homeostasis in the form of three interdependent sets of measures, which is a modern paradigm of state regulation and structural transformation of the national economy. We believe that achieving the

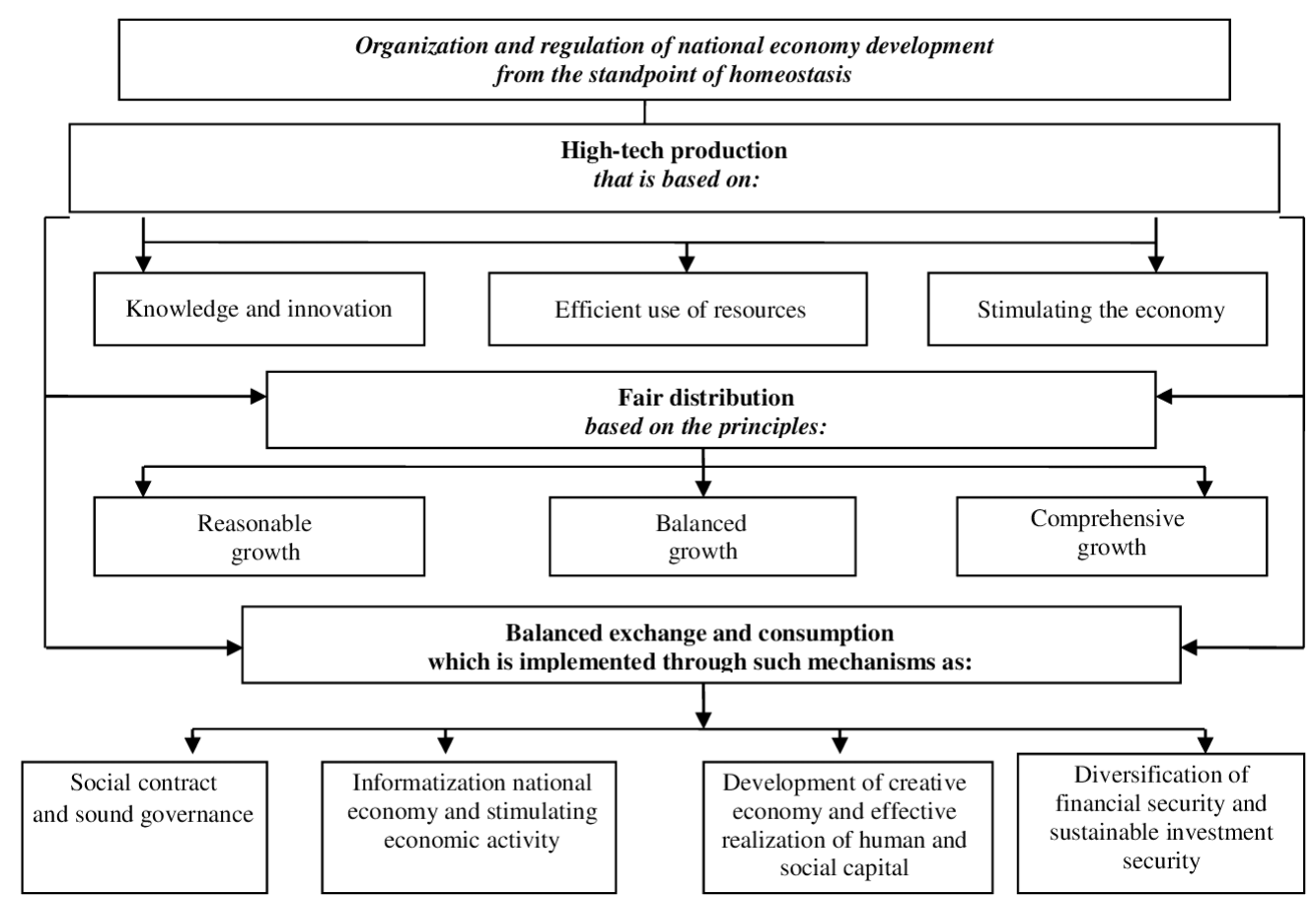

Fig. 4. Generalized structural and logical scheme of organization and regulation of national economy from the standpoint of homeostasis 
goals of structural transformation of the economy requires the introduction of effective mechanisms of economic development, which should complement and strengthen each other, creating synergies and accelerating economic growth.

\section{References.}

1. Ermolenko, A. (2016). Search for new ideas for the development of the Russian economy from the perspective of the theory of passionarity. Terra Economicus, 14(2), 90-99. https://doi.org/10.18522/2073-6606-2016-14-2-90-99.

2. Yermoshenko, M. (2016). Formation and distribution of profits in the information and energy theory of value. Aktualni problemy ekonomiky, 9(183), 9-15.

3. Halasiuk, V. (2019). Conceptual bases of transformation of economy of Ukraine. Monograph. Natsionalna Akademiia Upravlinnia. Retrieved from https://nam.kiev.ua/vydannya-akademivi-monografii.html.

4. Tsyhanova, N. (2019). Financial innovations and their role in the development of innovative entrepreneurship. Section 1. Innovatsiini napriamy rozvytku finansovoho rynku, 94-96.

5. Knell, M. (2015). Schumpeter, Minsky and the financial instability hypothesis. Journal of evolutionary Economics, 25, 293-310. https://doi.org/10.1007/s00191-014-0370-8.

6. Pareto, V. (2019). Compendium in general sociology. ISBN: 978-5-7598-0573-1.

7. Hnatenko, I., Orlova-Kurilova, O., Shtuler, I., Serzhanov, V., \& Rubezhanska, V. (2020). An approach to innovation potential evaluation as a means of enterprise management improving/ International Journal of Supply and Operations Management, $7(1), 112-118$.

8. Mykhailiuk, M. (2018). Innovative type of reproduction as a factor in achieving economic equilibrium of the transformation system of Ukraine. Retrieved from https://repository. mruni. eu/handle/007/16332.

9. Akamatsu, K. (2016). Biography and Long Cycles Theory. Kondratieff Waves: Cycles, Crises, and Forecasts, 65-81.

10. New Economy Allocation (n.d.). What is the New Economy? Retrieved from http://neweconomy. net/about/what-isthe-new-economy.

11. The Global Competitiveness Report/World Economic Forum (n.d.). Retrieved from https://www.weforum.org/reports.

12. Chyrkova, E. (2017). Synergetic methodology in economics. Ekonomika i sotsyum, (4), 1982-1987.

13. Pavlov, V. (2019). Formation and development of innovation system: theory, methodology, practice: monograph. Natsionalna Akademiia Upravlinnia.

14. Solokha, D. (2015). Theoretical and methodological bases of regulation of economic processes: from crisis to sustainable development: monograph (O. Kendiukhova, Ed.).

15. Raizberh, B., \& Tuliakov, A. (2015). Current state and problems of application of the target program approach in planning and management of the Russian economy. Ekonomika i upravleniye sobstvennostiu, 20-24.

16. Cherlenyak, I., Domyshche-Medyanik, A., Voitovych, S., \& Shtuler, I. (2017). Conditions of formation and stimulation of the activators of innovative development of Ukraine. Problems and Perspectives in Management, 15(4), 1-17. https://doi. org/10.21511/ppm.15(4).2017.13.

17. Huzhva, I. (2018). Updates of Ukraine's foreign trade policy: monograph. Natsionalna Akademiia Upravlinnia.

18. Filipenko, A. (2016). International economic integration: modern theoretical discourse. Naukovyi Visnyk Dyplomatychnoi Akademii Ukrainy, 23(3), 54-61.

\section{Парадигма державного регулювання та структурної трансформації національної економіки 3 позицій гомеостазису}

\author{
Ю. В. Гончаров ${ }^{1}$, І. Ю. Штулер ${ }^{2}$, В. В. Сержанов ${ }^{3}$, \\ T. O. Макух ${ }^{4}$
}

1 - Міжнародний економіко-гуманітарний університет імені академіка Степана Дем'янчука, м. Рівне, Україна, e-mail: goncharov_yv@ukr.net

2 - Національна академія управління, м. Київ, Україна 3 - Ужгородський національний університет, м. Ужгород, Україна

4 - Рівненський інститут Університету «Україна», м. Рівне, Україна

Мета. У роботі представлено обгрунтування парадигми державного регулювання та структурної трансформації національної економіки. Проблемою, що порушується - $є$ питання екзистенції національної економіки до розвитку з позицій гомеостазису за допомогою аналізу існуючого стану на відповідність тим умовам, що склалися та можливість адаптації до змін.

Методика. У процесі роботи здійснювалися дослідження, засновані на ключових положеннях сучасної економічної теорії й новітніх концепціях економічного розвитку. Використовуються методи теоретичного моделювання та структурно-логічного аналізу, систематизації, групування, логічного узагальнення. Для досягнення мети використані загальнонаукові й спеціальні методи дослідження процесів і явищ, а саме: методи теоретичного аналізу й синтезу, для пояснення процесів взаємозв'язку, виокремлення ключових елементів і характеристики інших, важливих для дослідження категорій. Застосування системно-структурного підходу дало можливість розкрити парадигму державного регулювання та структурної трансформації національної економіки з позиції гомеостазису.

Результати. Поступовість розвитку будь-якої економічної системи відбувається циклічно й відчувається негативний вплив кон'юнктурних коливань. Одним зі станів, котрий притаманний розвитку, є трансформація економічної системи, шо спричинена кризою. На мікрорівні для економічної системи зміст, стан і глибина кризи проявляється в загостренні суперечностей, що не дає в повній мірі використовувати національні ресурси. На макрорівні це проявляється у збільшенні чисельності безробітних, пониженні коефіцієнта завантаження виробничих потужностей тощо. Такий економічний стан потребує нової парадигми державного регулювання та структурної трансформації національної економіки з позицій гомеостазису. Тенденції розвитку інших країн і потенціал України визначають множинність ідей шляхом поєднання елементів світового досвіду моделей економічного розвитку. Встановлено, що «ідеальна» модель розвитку національної економіки в рамках нової парадигми державного регулювання та структурної трансформації національної економіки з позиції гомеостазису має бути врахована при створенні комплексної системи забезпечення цілісності існування й безпеки національної економіки в залежності від характеру впливу зовнішнього середовища

Наукова новизна. Новизна дослідження полягає в пошуку ефективного поєднання внутрішніх і зовнішніх механізмів, імперативів, методів та інструментів, котрі потрібно враховувати при створенні комплексної системи розвитку економіки. Одним із напрямів покращення $\epsilon$ побудова моделі такого розвитку з позиції гомеостазису в рамках парадигми державного регулювання та структурної трансформації національної економіки. Концепція гомеостазису наразі є основоположною в розвитку суспільства. За результатами здійснених наукових пошуків визначені форми впливу на розвиток національної економіки з позицій гомеостазису, а також запропонована узагальнена структурно-логічна схема організації й регулювання розвитку національної економіки з цієї ж позиції.

Практична значимість. Результати дослідження можуть бути використані представниками влади, науковця- 
ми та практиками для розробки сценаріїв економічного розвитку національної економіки.

Ключові слова: економічна система, рівновага, гомеостазис, стійкість, соціально-економічний розвиток

\section{Парадигма государственного регулирования и структурной трансформации национальной экономики с позиций гомеостазиса}

\author{
Ю. В. Гончаров ${ }^{1}$, И. Ю. Штулер ${ }^{2}$, В. В.Сержанов ${ }^{3}$, \\ T. A. Макух ${ }^{4}$
}

1 - Международный экономико-гуманитарный университет имени академика Степана Демьянчука, г. Ровно, Украина, e-mail: goncharov yv@ukr.net

2 - Национальная академия управления, г. Киев, Украина 3 - Ужгородский национальный университет, г. Ужгород, Украина

4 - Ровенский институт Университета «Украина», г. Ровно, Украина

Цель. В работе представлены обоснования парадигмы государственного регулирования и структурной трансформации национальной экономики. Проблема, которая требует решения - вопрос экзистенции национальной экономики к развитию с позиций гомеостазиса при помощи анализа существующего состояния на соответствие тем условиям, которые сложились и возможность адаптации к изменениям.

Методика. В процессе работы осуществлялись исследования, основанные на ключевых положениях современной экономической теории и новейших концепциях экономического развития. Использованы методы теоретического моделирования и структурно-логического анализа, систематизации, группировки, логического обобщения. Для достижения цели использованы общенаучные и специальные методы исследования процессов и явлений, а именно: методы теоретического анализа и синтеза, для объяснения процессов взаимосвязи, выделения ключевых элементов и характеристики других, важных для исследования, категорий. Применение системно-структурного подхода позволило раскрыть парадигму государственного регулирования и структурной трансформации национальной экономики с позиций гомеостазиса.

Результаты. Поэтапность развития любой экономической системы происходит циклически, ощущается не- гативное влияние конъюнктурных колебаний. Одним из состояний, которое соответствует развитию, является трансформация экономической системы, вызванная кризисом. На микроуровне для экономической системы содержание, состояние и глубина кризиса проявляются в обострении противоречий, что не дает в полной мере использовать национальные ресурсы. На макроуровне это проявляется в увеличении численности безработных, понижении коэффициента загрузки производственных мощностей прочее. Такое экономическое положение нуждается в новой парадигме государственного регулирования и структурной трансформации национальной экономики с позиций гомеостазиса. Тенденции развития других стран и потенциал Украины определяют множественность идей путем объединения элементов мирового опыта моделей экономического развития. Установлено, что «идеальная» модель развития национальной экономики в рамках новой парадигмы государственного регулирования и структурной трансформации национальной экономики с позиции гомеостазиса должна быть учтена при создании комплексной системы обеспечения целостности существования и безопасности национальной экономики в зависимости от характера воздействия внешней среды.

Научная новизна. Новизна исследования состоит в поиске эффективного сочетания внутренних и внешних механизмов, императивов, методов и инструментов, которые нужно учитывать при создании комплексной системы развития экономики. Одним из направлений улучшения является построение модели такого развития с позиции гомеостазиса в рамках парадигмы государственного регулирования и структурной трансформации национальной экономики. Концепция гомеостазиса сейчас является основополагающей в развитии общества. По результатам проведенных научных изысканий определены формы влияния на развитие национальной экономики с позиций гомеостазиса, а также предложена обобщенная структурно-логическая схема организации и регулирования развития национальной экономики с этих же позиций.

Практическая значимость. Результаты исследования могут быть использованы представителями власти, учеными и практиками для разработки сценариев экономического развития национальной экономики.

Ключевые слова: экономическая система, равновесие, гомеостазис, устойчивость, социально-экономическое развитие

Recommended for publication by M. M. Yermoshenko, Doctor of Economic Sciences. The manuscript was submitted 10.04.20. 